\title{
Los pliegues de la subjetividad: individuo y responsabilidad moral en la Grecia Antigua*
}

Folding and subjetivation: individual and moral responsibility in Ancient Greek

Por: Milena Lozano Nembrot*

UBA-CONICET

Buenos Aires, Argentina

Email: miluloz@hotmail.com

Fecha de recepción: 21/02/2019

Fecha de aprobación 01/04/2019

Doi: $10.30972 /$ nvt.0143711

\section{Resumen}

La moral griega clásica ha sido objeto de diversas interpretaciones por parte de especialistas y filósofos. Por un lado, encontramos una línea exegética, de tradición alemana, que observa en la moral griega desde Homero a la época helenística un progresivo desarrollo, en donde se formarían por primera vez ciertas nociones básicas de la ética occidental. Por otro lado, a partir de los años setenta del siglo pasado se han hecho varias críticas a este tipo de posición, haciendo hincapié en las continuidades tanto dentro de los siglos de la Grecia Antigua como con respecto a la actualidad. El objetivo del presente artículo es, en primer lugar, trazar un mapa de estas dos líneas fundamentales en los estudios específicos sobre esta temática. De esta forma, la parte más extensa de este trabajo consistirá en un recorrido por los textos de los principales referentes de estas líneas de pensamiento, para observar sus similitudes y diferencias, y rastrear sus fundamentos filosóficos. En segundo lugar, propondremos brevemente un punto de partida concreto para analizar la ética griega y sus posibles cambios: la aparición y desarrollo del concepto de enkrateia o "dominio de sí", término que aparece recién en los testimonios del siglo IV a. C., pero que, como veremos, se origina en el ambiente intelectual del siglo $\mathrm{V}$ a.C. Por último,

\footnotetext{
* El presente trabajo ha sido realizado gracias a una Beca Interna Doctoral del Consejo Nacional de Investigaciones Científicas y Técnicas (CONICET) bajo la dirección de la Dra. María Angélica Fierro, a quien agradezco su apoyo. También agradezco los comentarios de uno de los evaluadores anónimos de la revista que me han permitido mejorar mi trabajo.

*Profesora en Filosofía (Facultad de Filosofía y Letras, Universidad de Buenos Aires). Doctoranda en el Doctorado en Filosofía, Facultad de Filosofía y Letras, Universidad de Buenos Aires-Consejo Nacional de Investigaciones Científicas y Técnicas (Argentina).
} 
consideraremos este tema desde la lectura de Foucault, y la interpretación deleuziana de esta, la cual coloca como clave para comprender la ética antigua el concepto de gobierno de sí. De esta manera, a partir de lo visto en el segundo apartado, a la luz de la filosofía foucaultiana, propondremos un modo de acercamiento a la ética griega que permita apreciar los cambios dentro de esta, sin suponer una visión evolucionista de la historia de la moral.

Palabras clave: enkrateia, gobierno de sí, moral antigua, ética socrática, Foucault

\section{Abstract}

Greek morality has been subject of various interpretations by scholars and philosophers. On one hand, there is an exegetic line, which arises from German tradition and sees in Greek morality from Homer to Hellenistic times a progressive development where basic notions of Western Ethics were originated. On the other hand, from the seventies in the twentieth century on, many critical lines to this positions have emphasize the continuities regarding moral notions within Greek culture, and between the Greeks and us. Here I will firstly map these two main lines of interpretation about this topic. I will analyze both of them, in order to see the similarities and differences between them and appreciate their philosophical grounds. Secondly, I will propose a specific starting point to see the possible changes in Greek morality: the beginning and development of the concept of enkrateia or self-control. I will show that, although this word appears for the first time in the testimonies of the fourth century B.C., it originated in the fifth century. Lastly, I will consider this topic from the point of view of Foucault's philosophy and its Deleuzian interpretation.

Key words: enkrateia, self-control, Greek morality, Socratic ethics, Foucault

\section{Cómo citar este artículo:}

APA: Nembrot, M. L. (2019). Los pliegues de la subjetividad: individuo y responsabilidad moral en la Grecia Antigua. Nuevo Itinerario, 14 (1), 175-207. Recuperado de: (agregar dirección web) 


\section{Introducción}

El estudio de la filosofía y la cultura antigua, si no lo consideramos meramente como una reconstrucción del pasado, es también una reescritura permanente desde nuestro presente y nuestras preocupaciones éticas y teóricas. A partir de aquí, historiar en filosofía antigua puede ser un dialogar con el pasado: leer la antigüedad desde nuestros problemas, y releer la contemporaneidad con la ayuda de la perspectiva griega. ${ }^{1}$ Esto es especialmente cierto en el ámbito de la ética, donde parece que las cosas avanzan más lentamente que en otras disciplinas, y en movimientos no lineales. Desde este punto de vista, el mundo clásico nos permite comparar con un otro que puede poner en jaque ciertas categorías naturalizadas de la cultura actual. ${ }^{2}$ A su vez, la forma en que leemos las éticas antiguas también dice mucho de los fundamentos filosóficos que, explícita o implícitamente, son aportados al estudio.

La moral griega clásica ha sido objeto de numerosos análisis y de diversas interpretaciones de especialistas y filósofos. Por un lado, encontramos una línea exegética, de tradición alemana, que observa en la moral griega, desde Homero a la época helenística, un progresivo desarrollo, en donde se formarían por primera vez ciertas nociones básicas de la ética occidental. Por otro lado, a partir de los años setenta del siglo pasado se han realizado varias críticas a este tipo de posición, haciendo hincapié en las continuidades que pueden observarse al respecto tanto al interior del pensamiento griego mismo como de este en relación con la contemporaneidad.

El objetivo del presente artículo es, en primer lugar, trazar un mapa de estas dos líneas fundamentales en los estudios específicos sobre la temática presentada. Por ello, la primera parte de este trabajo consistirá en un un recorrido por los textos de los principales referentes de estas líneas de pensamiento, para ver sus similitudes y diferencias, y rastrear sus fundamentos filosóficos. Tomaremos como eje para ello la

${ }^{1}$ Véase Soares (2000); Valenzuela (2017).

2 "El mundo antiguo, en efecto, es un excelente laboratorio de experimentación: nos permite comparar las actitudes, los comportamientos y las representaciones y nos permite poner en perspectiva categorías que nos parecen -sin razón- evidentes." (Boehringer, en prensa: 2; véase también al respecto Boehringer, 2018, pp. 21-31). 
presencia -o ausencia- de un individuo consciente de sí mismo y responsable de sus actos. En segundo lugar, propondremos un punto de partida concreto para analizar la ética griega y sus cambios, procurando no apelar a éticas evolucionistas: la aparición y desarrollo del concepto de enkrateia o "dominio de sí", término que aparece recién en los testimonios del siglo IV a. C., pero que, como se mostrará, se origina en el ambiente intelectual del siglo $\mathrm{V}$ a.C. A partir del relevamiento de ciertos pasajes en donde se utiliza el adjetivo enkratēs y sus cognados (kratēo, kreissōn), veremos cómo el sentido más antiguo de dominar a algo a alguien se vuelve sobre sí para referirse al control de uno mismo. De esta manera, se genera una reflexividad que no encontramos en testimonios anteriores. Por último, veremos cómo esta nueva relación con uno mismo es interpretada desde la filosofía de Michel Foucault, y la interpretación deleuziana de esta, que coloca el concepto de dominio de sí como clave para comprender la ética antigua desde la perspectiva contemporánea. De esta forma, a partir de lo visto en el segundo apartado, a la luz de la filosofía foucaultiana, podremos esbozar una propuesta alternativa para apreciar la cultura griega y su relación con nosotros. ${ }^{3}$

La hipótesis general de este trabajo, la cual se desarrollará a partir de las tres secciones mencionadas, es que es posible pensar ciertos cambios y desarrollos en la moral griega, atados a las condiciones históricas que los posibilitan, sin por ello suponer que hay estadios de la historia de la ética más evolucionados o avanzados que otros. Veremos puntualmente esto con el ejemplo de la enkrateia en el segundo apartado. En segundo lugar, para observar la relación entre los griegos y la actualidad, tomaremos como base la propuesta foucaultiana, que nos permitirá acercar a los griegos a nuestros tiempos sin por eso negar su otredad histórica.

3 Utilizamos aquí indiscriminadamente las palabras "moral" y "ética", no porque sean exactamente lo mismo sino debido a que el campo de estudio aquí estudiado abarca ambas. La división tradicional supone que la moralidad de una cultura son los principios, criterios y valores que suponen las respuestas a esta familiar experiencia. En cambio, la ética o filosofía moral es el pensamiento racional y sistemático sobre la relación entre cultura y razón (Dover, 1974, p. 1). Sin embargo, etimológicamente, el término "moral" proviene del latín mos, que significa costumbre o hábito, y "ética" del griego éthos, cuyo sentido es muy similar. Vemos entonces que su origen era el mismo, y posiblemente para los antiguos no había una diferenciación clara entre ambas. Por otra parte, Foucault diferencia la moral, concebida como los códigos de conducta de determinada sociedad, de la ética, que considera como la relación consigo mismo para constituirse como sujeto moral (Foucault, 2013 [1994], p. 140). Sobre esto volveremos más abajo. 


\section{Lecturas sobre la moral griega y la relación con la actualidad}

\section{(a) La mirada evolucionista}

En primer lugar, encontramos una línea interpretativa que podríamos llamar "evolucionista" o "desarrollista", ya que supone que en el campo de la ética ha habido un desarrollo progresivo desde los antiguos hasta la actualidad. A su vez, estos autores -a excepción de Adkins (1960), como se verá a continuación- plantean también un avance dentro de la misma cultura griega, desde la época homérica hasta la helenística. Dentro de los estudios específicos sobre el tema, los principales representantes de esta línea -y los más criticados en las últimas décadas- son B. Snell (1953 [1946]) y A. W. H. Adkins (1960).

En El descubrimiento del espíritu: estudios sobre la génesis del pensamiento (1953 [1946]), desde un enfoque hegeliano -que se puede observar en el título de la obra, Die Entdeckung des Geistes-, Snell describe cómo aparece y se desarrolla la conciencia del espíritu (Geistes) en la Grecia Clásica. ${ }^{4}$ A partir del estudio de los términos homéricos en relación con las cuestiones humanas, concluye que en la llíada y la Odisea no es posible encontrar una noción de individuo, ya que no existían términos para designar el alma ni el cuerpo del sujeto como un todo, sino solo una serie de partes sin una unidad común. ${ }^{5}$ De esta ausencia de un sujeto unitario -que el

${ }^{4}$ Según este autor, el espíritu se "descubre" en un sentido particular, ya que solo existe en la medida en que el hombre tiene conciencia de él, debido a que implica autoconciencia. Pero no es una invención, como la de una herramienta, ya que, si bien en la cultura homérica no lo encontramos como tal, sí existía de otra forma (Snell, 1953 [1946], p. 1). Vemos aquí, en la primera página del libro, la base fuertemente hegeliana de la forma de pensar la historia como develamiento progresivo del espíritu (Hegel, 2009 [1807], pp. 161-163; 166-169).

${ }^{5}$ Tanto para lo que llamamos cuerpo como lo que llamamos alma existía una variedad de términos distintos: para lo corporal denominaban sōma al cadáver; demas a la figura o estatura; guia a las articulaciones; melea a los miembros; chrōs a la piel como superficie del cuerpo. En cuanto lo anímico, utilizaban psychē para referirse al último aliento en el momento de morir y al alma de los difuntos como fantasmas o imágenes de la persona viva; thymos para el aliento vigoroso de la vida o el órgano del movimiento o de lo pasional; noos para el pensamiento, percepción u órgano de producción de ideas claras. Por otra parte, había términos para designar órganos de conciencia corporales como phrenes (diafragma, pulmones pero también mente) o kradie (corazón). Véase también Onians (1951, pp. 13-84). 
autor ve como una falta-, deduce que no podía haber una noción de responsabilidad moral individual, pues no existía un agente único desde el cual surjan las acciones y elecciones humanas, sino que, para el hombre homérico, estas eran producidas a partir de condicionamientos y fuerzas externas -principalmente provenientes de los dioses-. La noción de individuo consciente de sí mismo comenzaría a aparecer en la lírica griega del período arcaico y se terminaría de desarrollar en el período clásico con la tragedia y la filosofía. Podemos observar aquí que el parámetro para juzgar el verdadero individuo es el de un ser unitario y consciente de sí mismo, ajeno a la concepción griega. Sin embargo, si quitamos el aspecto normativo, este estudio permite observar, a través del gran trabajo erudito de los textos homéricos y la lengua griega, una visión sobre el ser humano y su relación con el mundo muy distinta a la existente hoy, y en este sentido puede ser valiosa para desnaturalizar o historizar la concepción moderna que predomina actualmente sobre estos temas.

Por otra parte, Adkins adopta explícitamente un punto de vista kantiano, el cual considera universal -llega a afirmar que "somos todos kantianos ahora" (Adkins, 1960, p. 2)-, y se sorprende de que el concepto de responsabilidad moral ocupe un lugar menor en las reflexiones éticas de los griegos. Según este autor, la pregunta básica para el agente es cuál es mi deber en tal circunstancia y desde esta postura pretende comprender la gran diferencia entre "nuestro" sistema moral y el griego. ${ }^{6}$ Comparte con Snell la antropología filosófica moderna para juzgar a los griegos; sin embargo, estos difieren en que Adkins plantea que la evolución dentro del pensamiento moral griego fue mínima, ya que todos estaban condenados a la misma ética "defectuosa" por su tipo de visión de mundo (Adkins, 1970, p. 8). Los griegos no pudieron concebir

6 Esta perspectiva es muy similar a la crítica que realiza el mismo Kant a las éticas anteriores a él, que se hallan en un estado de heteronomía: "Y no es de admirar, si consideramos todos los esfuerzos emprendidos hasta ahora para descubrir el principio de la moralidad, que todos hayan fallado necesariamente (...) Pues cuando se pensaba al hombre sometido solamente a una ley (sea la que fuere), era preciso que esta ley llevase consigo algún interés, atracción o coacción, porque no surgía como ley de su propia voluntad, sino que esta voluntad era forzada, conforme a la ley, por alguna otra cosa a obrar de cierto modo. Pero esta consecuencia necesaria arruinaba irrevocablemente todo esfuerzo encaminado a descubrir un fundamento supremo del deber. Pues nunca se obtenía deber, sino necesidad de la acción por cierto interés, ya fuera este interés propio o ajeno. Pero entonces el imperativo había de ser siempre condicionado y no podía servir para el mandato moral. Llamaré a este principio el de la autonomía de la voluntad, en oposición a cualquier otro que, por lo mismo, calificaré de heteronomía. (Kant, Fundamentación de la metafísica de las costumbres, 4: 433). 
un concepto de responsabilidad moral acertado, ya que tenían como base ciertas suposiciones homéricas y hábitos de pensamiento que ni Platón ni Aristóteles cuestionaron (Adkins, 1970, p. 348). ${ }^{7}$

Además de a Snell, Adkins sigue explícitamente el desarrollo de Dodds (1960 [1951]). En Los griegos y lo irracional, este autor realiza un análisis de los aspectos irracionales de la cultura griega, desde un enfoque que combina ciertas teorías antropológicas y psicológicas. ${ }^{8}$ Aunque marca su diferencia con Snell (1953 [1946]) y Voigt (1972) respecto de la idea de que el hombre homérico no tenía conciencia de la libertad personal o no era capaz de distinguir entre su yo y las intervenciones psíquicas de agentes externos divinos o demoníacos, sigue a Snell en la idea de que el aquel no poseía un concepto unificado de lo que nosotros llamamos "alma" o "personalidad", ya que poseía el hábito de objetivar los impulsos emocionales y tratarlos como una fuerza que viene desde el exterior (Dodds, 1960 [1951], pp. 27; 30). También coloca el momento bisagra en la época arcaica, donde se gestaría la conciencia de la inseguridad humana y la condición desvalida del hombre, lo que genera que este se vuelva sobre sus sentimientos. ${ }^{9}$ Este proceso se completa en la época clásica y se puede observar desde la figura de Sócrates, pero también en Eurípides, sobre todo con Medea e Hipólito, quien con su irracionalismo representa la otra cara de la moneda del racionalismo socrático.

${ }^{7}$ El problema principal del sistema de valores homéricos -cuyos fundamentos se mantendrán a lo largo de toda la historial moral griega- es que se basa en las virtudes de la guerra (aretē homérica) y las coloca por encima de las virtudes tranquilas (quiet) o cooperativas como la sōphrosynē, por lo que el héroe puede perseguir su interés a expensas de los otros sin que eso dañe su aretē (Adkins, 1970, p. 46). Por otra parte, según Adkins, los dioses avalan este "agathos-standard" y están lejos de ser justos (Adkins, 1970, p. 62). Ni la filosofía Platónica ni la Aristotélica, a pesar de sus intentos, habrían logrado dar una respuesta satisfactoria a todos estos problemas de la moral griega tradicional (Adkins, 1970, p. 384).

${ }^{8}$ A pesar de su tema de interés y de que remarca la presencia de los elementos no racionales incluso dentro del llamado "iluminismo griego", les atribuye a estos una carga fuertemente negativa, oponiéndolos a la "luz de la razón". A su vez, utiliza términos como "evolución" y "retroceso" a los aspectos irracionales. Por ejemplo, afirma que no se ha notado muy a menudo el "rebrote de la religión popular en la Época de la llustración (...) aparecieron hendiduras en la fábrica, y a través de esas hendiduras empezaron a asomar, aquí y allí, cosas desagradablemente primitivas. (...) Concluiré este capítulo dando algunos ejemplos de lo que entiendo por regresión." (Dodds, 1960 [1951], p. 181, las itálicas son nuestras).

${ }^{9}$ Contra la idea tradicional de familia y de culpa heredada comienza a surgir "una verdadera visión del individuo como persona, con derechos personales y responsabilidades personales" (Dodds, 1960 [1951], p. 43). 
Sin embargo, si queremos ver los orígenes de esta línea de pensamiento, debemos ir más atrás en la historiografía alemana, con E. Rohde y W. Jaeger. En Pyché (2006 [1894]), Rodhe, que profesaba una amistad con Nietzsche, retoma a su manera el enfoque nietzscheano, siendo uno de los pioneros en estudiar seriamente la religión griega y sus aspectos irracionales o dionisíacos. ${ }^{10}$ Así, constituye un importante antecedente para el estudio de Dodds, tanto en la temática como en la utilización de una perspectiva antropológica, que se caracteriza por comparar las cultura griega con los llamados "pueblos primitivos". ${ }^{11}$

Por otra parte, W.W. Jaeger (2016 [1933]) -desde un lugar de exaltación y admiración del espíritu griego- también plantea un desarrollo progresivo en la moral griega, desde el mundo homérico basado en la idea de honor y en la aretē unida a la idea de cierto status social, hasta la internalización de la moral que se produce en la época clásica. Una figura clave para el desarrollo de la ética tal como la conocemos es Sócrates, quien desarrolla la idea del dominio de nosotros mismos, noción central de la cultura griega y la nuestra. "En el momento en que Sócrates dirige la vista a la naturaleza del problema moral aparece en el idioma griego de Atenas la nueva palabra enkrateia, que significa dominio moral de sí mismo, firmeza y moderación." (Jaeger,

10 Véase Nietzsche (2012 [1872]).

${ }^{11}$ Rohde aplica la teoría animista de la antropología inglesa al mundo griego, siguiendo las investigaciones de Herbert Spencer (Rohde, 2006 [1894], p. 11). Este último supone un evolucionismo naturalista: toda evolución, en el ámbito natural pero también en la cultura humana, comienza en una etapa más simple, en donde se hayan prefiguradas las etapas posteriores más complejas. De esta manera, esta corriente se propone estudiar, en los hombres llamados "primitivos", los gérmenes de nuestas propias concepciones. El problema del nacimiento del alma se traduce en la "tesis animista", que supone que los hombres creían en la realidad objetiva de las apariciones oníricas y de allí inferían una existencia doble en el hombre, la corpórea y la anímica, y luego esta conclusión se generaliza a los demás seres vivos que vemos. Esta línea interpretativa es criticada a partir de Lévy-Bruhl (1910) y luego por otros como W.F. Otto (1923), E. Bickel (1925), Jaeger (1952). Para una crítica a ambas posturas véase Eggers Lan (1967).

Rodhe explica que la psychē en Homero no era nada como lo que ahora pensamos que es el alma, y que el culto del alma en Grecia comenzaría recién en la época arcaica, especialmente con Píndaro y Esquilo, a partir del contacto con otras culturas, sobe todo con Oriente. Pero la concepción de la divinidad del alma tiene lugar por primera vez con la filosofía de Pitágoras, quien, basado en un fundamento ético-religioso, fue el primero en plantear al hombre como centro de investigación (Rohde, 2006 [1894], p. 201). Esta idea será retomada luego por muchos intérpretes -como Jaeger, Dodds, Mondolfo-. Rohde también remarca la importancia de la tragedia, sobre todo en la reflexión sobre el libre albedrío y la necesidad, tematizada progresivamente por Esquilo, Sófocles y por último Eurípides, autor influido fuertemente por la sofística (Rohde, 2006 [1894], pp. 219-239). Pero es recién con Platón que se le otorga la dignidad e inmortalidad al alma que heredarán tanto la literatura helénica como la cultura posterior (Rohde, 2006 [1894], p. 240). 
2016 [1933], p. 432). Esta palabra aparece simultáneamente en Jenofonte y Platón, además de en Isócrates, autor cercano al círculo socrático. De aquí saca la "irrefutable conclusión" de que se trata de un nuevo concepto que tiene sus raíces en el pensamiento ético de Sócrates y que cambiará por completo la moral griega. ${ }^{12}$

Toda esta corriente interpretativa posee un carácter evolucionista sobre la ética, o al menos desarrollista, con mayor o menor connotación negativa sobre las fases menos "evolucionadas". El problema principal de estos trabajos, como marcarán luego algunos de sus críticos (Gill, 1996, p. 41), no es el análisis en sí de los testimonios griegos, que suele estar realizado con suma erudición, sino los parámetros modernos con que los juzgan, los cuales estos autores consideran superadores. Desde aquí piensan las éticas griegas como deficientes respecto de las modernas, al mismo tiempo que las consideran el germen de lo que luego será la cultura occidental.

Antes de pasar a las críticas a esta visión y la propuesta que llamamos "continuista", es necesario mencionar una obra fundamental para el estudio de la moral griega, y en particular para el presente trabajo. En un punto medio entre las dos líneas aquí esquematizadas, encontramos el libro de K. Dover, Greek popular morality (1974), quien realiza un detallado análisis de la moral popular griega, con más recaudos que sus antecesores en el análisis de los textos, pero que mantiene ciertos puntos de contacto con los autores que aquí estudiados. Por un lado, critica la posición que sostiene que los griegos homéricos y arcaicos poseían una noción imperfecta de la

12 Esta línea de pensamiento la retomará fuertemente el filósofo ítalo-argentino Rodolfo Mondolfo (1997 [1962]). Desde su mirada hegeliana-marxista, manifiestamente evolucionista -y con ciertos tintes de la ética kantiana-, se pregunta en qué momento de la antigüedad el pensamiento occidental llega a la concepción de responsabilidad y libertad humana (Mondolfo, 1997 [1962], p. 9; sobre el marxismo de Mondolfo véase Ovide, 2006, Mondolfo, 1964). A ello Mondolfo responde que no es posible encontrarlos en el mundo homérico, que todavía se hallaba en una fase de "heteronomía", donde el juicio y la sanción procedían del exterior (Sobre la heteronomía como concepto kantiano véase Kant, 2007 [1785], p. 53). Coloca la clave del comienzo de la conciencia individual en los ritos mágicos de los pitagóricos, donde por primera vez se plantea la existencia de un juez interior. De este pensamiento se nutrirán luego Demócrito, Sócrates y Platón para desarrollar la concepción del alma y responsabilidad moral. Pero es Sócrates quien, a partir de la disolución de la autoridad exterior de la ley propia de la época de los sofistas, se abre paso hacia la afirmación de una ley interior. También refiere, como Jaeger (2016 [1933]), a la creación de la palabra enkrateia o autodominio a Sócrates, la cual lleva consigo implícito un nuevo concepto de libertad interior.

Por otra parte, Veggetti (2005 [1989]) sigue una línea similar. Aunque dice ir contra la teoría de Adkins (1970), toma varios de sus presupuestos y los de Snell (1953 [1946]). Como Jaeger y Mondolfo, coloca en el centro de la "interiorización” a Sócrates y Demócrito, quienes coinciden en la importancia de un buen orden interno y la interiorización de la ley de la ciudad. 
personalidad, pero hace hincapié en el hábito de externalización y personificación de las pasiones presente en los textos de la época, ${ }^{13}$ y le atribuye gran importancia moral. De esta manera, explica, un griego podría describir la secuencia de las propias acciones enteramente de manera que parezca que es un juguete de los seres sobrenaturales. Según este autor, los griegos parecían postular muchas más limitaciones que nosotros a sus acciones, y se consideraban condicionados por circunstancias y fuerzas fuera de su control. Este planteamiento es interesante para pensar el posible cambio que se produjo en las éticas del período clásico, sobre todo con Sócrates y sus seguidores, tal como planteará L. Rossetti (2008), sobre lo cual volveremos en el segundo apartado.

\section{(b) La mirada continuista}

En las últimas décadas aparecieron varias críticas a los autores aquí mencionados, sobre todo desde los estudios anglosajones. Estos últimos rechazan los presupuestos modernos de la línea precedente, así como la posibilidad de aplicar las nociones de evolución y desarrollo en al ámbito de la moral. En cambio, proponen una mirada distinta, que se centra en las continuidades en la moral tanto dentro de los siglos de la Grecia Clásica, de Homero a a Aristóteles y la época helenística, así como de los griegos respecto a nosotros.

Entre los primeros en discutir la interpretación clásica respecto de los poemas homéricos se encuentra $\mathrm{H}$. Lloyd-Jones (1971). Este autor critica la idea -presente en Dodds (1960 [1951]), Chantraine (1952), Adkins (1960)- de que la religión griega y la moralidad estaban separadas en las obras de Homero. En particular, rechaza la metodología de Snell (1953 [1946]) y Fränkel (1962) que suponen que para estudiar la moral de una cultura es suficiente con listar y analizar las palabras que indican conceptos morales, ya que es necesario completar este método con el estudio de las acciones concretas de la obra o la sociedad estudiada (1971, p. 2). A su vez, afirma que la diferencia en cuanto a la teología y moral entre los textos, tanto entre la llíada y la Odisea como entre estos poemas y la lírica, no radica en la distancia temporal y

\footnotetext{
${ }^{13}$ Concepto que podemos asimilar a la intervención psíquica de Dodds (1960 [1951], p. 14).
} 
conceptual -como usualmente se entendía-, sino que se debe a una mera diferencia en el estilo y propósito de la obra (Lloyd-Jones, 1971, p. 30). Por ejemplo, en la lírica, donde muchos autores ven el momento clave en el desarrollo de la moral individual, no habría una nueva noción de sujeto, sino que por su género pone más de relieve la individualidad del poeta y sus sentimientos, pero ello no significa que haya cambiado la concepción del individuo (Lloyd-Jones, 1971, pp. 36;52). ${ }^{14}$

Se puede observar aquí que este autor pone el énfasis en los elementos que se mantienen a lo largo de la historia griega, planteando una importante continuidad en la moral, desde los poemas homéricos hasta la tragedia de la época clásica, y así la abstrae de las condiciones históricas que la posibilitan. Por otra parte, si bien pueden ser acertadas sus precauciones respecto del análisis del lenguaje para estudiar una sociedad, no podemos negar que la lengua es un aspecto fundamental de una sociedad, y refleja -al mismo tiempo que influye- en el modo de pensar de esta. Sobre todo, es un factor importante para comprender la moral de determinada sociedad, al ser el material estudiado textos literarios o filosóficos.

Luego, varios especialistas han continuado este planteo desde la ética contemporánea, especialmente la teoría anglosajona de la acción. Es el caso de M. Nussbaum (1988), que en su célebre libro sobre el lugar de la fortuna (thychē) en la tragedia y filosofía griega, releva los problemas de ver a los griegos desde una posición kantiana, tan común en la academia, que supone una distinción neta entre lo que es moral y lo que no lo es (Nussbaum, 1988, p. 32). ${ }^{15}$ En cambio, propone para entender a los griegos la metáfora de la planta de Píndaro, en donde el individuo es un agente activo que realiza ciertas acciones o procesos, pero a su vez es pasivo y dependiente del entorno. Nussbaum defiende que para analizar a los griegos es más provechosa la teoría contemporánea de la acción, que, según la autora, se adapta mejor a las creencias de los griegos -y también a las nuestras de hoy en día- sobre estos temas.

${ }^{14}$ Lo mismo ocurriría en la época clásica con la tragedia. Las diferencias que encontramos se deberían al género particular, mientras que las ideas de religión y justicia aquí presentes son similares a las de los poemas homéricos. Por otra parte, respecto del problema de la causalidad de las acciones en Homero, argumento principal de Snell para afirmar que no existía la noción de individuo unificado, defiende que no hay contradicción en suponer una doble intencionalidad de los actos, es decir, una doble motivación de responsabilidad, una humana y una divina (Lloyd-Jones, 1971, p. 10).

${ }^{15}$ También realiza una crítica a Adkins en Nussbaum (1976). 
De una perspectiva similar parte B. Williams en Shame and Necessity (1993). Comienza su libro explicando que, a diferencia del enfoque antropológico -corriente a partir de Dodds-, que tiende a marcar las diferencias entre los griegos y nosotros, él procurará observar las similitudes no reconocidas que tenemos con los griegos, aunque sin negar por ello su otredad. Por otra parte, argumenta que las éticas de carácter evolucionista son engañosas tanto histórica como éticamente, principalmente porque la noción de un desarrollo moral consciente es un mito, y no es cierto que tengamos hoy una conciencia prístina sobre lo que es la obligación moral (Williams, 1993, p. 5). En este sentido, Williams dice retomar a Nietzsche, quien toma su pasión por el mundo griego para criticar la modernidad, y afirma que es necesario ir hacia los antiguos, ya que en sus planteamientos podríamos reconocer ciertas ilusiones del pensamiento moderno, y ver que en ciertas cuestiones ellos estaban en terreno más firme que nosotros (Williams, 1993, p. 9). El autor afirma que no es posible encontrar en los textos homéricos una teoría del alma y de la mente, como pretendió sin éxito Snell, pero que sí se puede hallar allí la base de una teoría de la acción, que supone atribuir acciones a los hombres, también deliberaciones, por cuyo resultado actúan (Williams, 1993, p. 33). ${ }^{16}$ Desde aquí, Williams sostiene que si bien no hay una palabra en Homero para "voluntad" o "decisión", es posible encontrar esos conceptos allí. Sin embargo, al buscar estas nociones en los textos homéricos, ¿no cae en el mismo error que había criticado previamente a Snell de adjudicar ciertos prejuicios modernos -o contemporáneos en este caso- sobre el ser humano a la ética antigua? Si bien no busca un alma unificada, Williams pretende localizar en los griegos ciertas nociones de la teoría de la acción, suponiendo así que esta vale para una suerte de ser humano universal.

A continuación, un libro fundamental dentro de esta nueva línea de interpretación de la moral antigua es el de Ch. Gill (1996). En el primer capítulo de su libro realiza un minucioso análisis de los fundamentos filosóficos de Snell y Adkins. Concluye que estos suponen una concepción post-cartesiana del yo y una post-

${ }^{16}$ Colin McGinn define a Williams y su filosofía como una mezcla de analítico y humanista: "Williams is a principled anti-moralist, a brilliant anti-theorist, an original blend of logic and humanism, an insider's outsider." https://www.nybooks.com/articles/2003/04/10/isnt-it-the-truth/ 
kantiana de la decisión moral, sumado a una visión hegeliana de la historia como evolución dialéctica del espíritu hacia un nivel cada vez mayor de autoconciencia (Gill, 1996, p. 34). Sin embargo, especialmente respecto de Snell, aclara que su intención no es criticar el análisis del material homérico, sino los presupuestos con que opera (Gill, 1996, p. 41). El problema principal de estos autores es que colocan las ideas modernas sobre personalidad y mismidad como normativas y clasifican las concepciones de los griegos como relativamente primitivas o desarrolladas según este parámetro. En cambio, sostiene Gill, hay más continuidad hoy con los griegos de lo que se supone: lo que los autores clásicos notan en Homero sobre la falta de unidad del yo es precisamente lo que proponen ciertas teorías contemporáneas, desde Freud hasta corrientes analíticas anglosajonas (Gill, 1996, p. 42). ${ }^{17}$ Siguiendo a Gaskin (1990), analiza los textos homéricos marcando las similitudes con otros pensadores griegos como Aristóteles y los estoicos, iluminado por la teoría anglosajona de la acción. Entonces, según este autor, para los griegos las emociones y deseos reflejaban creencias y conocimientos, y el conflicto interno no era concebido típicamente entre la razón y la pasión, sino entre dos tipos de creencias o razonamientos (Gill, 1996, p. 233). De esta manera, termina adjudicando a los griegos una ética analítica muy estricta, como si desde Homero o los trágicos consideraran la elección ética como un tipo de silogismo práctico, lo cual es difícil de concebir incluso para los filósofos previos a Aristóteles. ${ }^{18}$

Por último, vale la pena mencionar el libro de A. Rademaker sobre la sōphrosynē (2004). Si bien su objetivo es dar una descripción semántica sincrónica de los usos de sōphrōn, sōphrosynē, sōphronein y sus cognados en los tiempos de Platón,

${ }^{17}$ A diferencia de la posición moderna que define como "subjetiva-individualista", este autor propone una concepción "objetiva-participante", que se basa en una concepción del yo en diálogo consigo mismo (self in dialog), esto es, la mente como un complejo de funciones más que como un yo unitario y consciente. La concepción "objetiva-participante" supone que la vida psicológica humana se centra en la relación o el diálogo entre partes o funciones; que la vida ética es formada y expresada por la participación en un discurso interpersonal y comunal; y que el debate reflexivo o dialéctico constituye el medio por el cual los seres humanos pueden propiamente determinar las bases de su vida compartida. (Gill, 1996, p. 236). B. Wald (2003) sigue esta idea y analiza la concepción objetivaparticipante en República y Gorgias de Platón.

${ }^{18}$ Esto se ve bien en la interpretación de Medea que hace Gill. Por otra parte, Bieda (2006) plantea una alternativa interesante, más cercana a la de Snell en cuanto que piensa la oposición razón y pasión, pero quitándole el matiz kantiano que considera a las pasiones como algo amoral y a la razón como la única instancia ética relevante. 
en los primeros capítulos realiza un análisis de los distintos sentidos de estas palabras desde Homero a los tragediógrafos, Aristófanes y los oradores. ${ }^{19}$ De manera similar a Lloyd-Jones, considera que el énfasis en uno u otro aspecto de la sōphrosynē se debe a una cuestión de estilo literario y no a cambios en la moral griega. Su conclusión es que los usos más activados, esto es, los sentidos prototípicos de la sōphrosynē en los tiempos de Platón -pero que están presentes en el recorrido por los siglos previos- es el control de los deseos en los hombres, la fidelidad en las mujeres y la quietud y obediencia en los y las jóvenes (Rademaker, 2004, p. 251). El control de los deseos y placeres, sentido fundamental de la sōphrosynē del varón libre, según este autor estaría ausente en las obras de literatura con temática heroica o grandilocuentes (grand) como Homero, Esquilo, Sófocles o Heródoto (Rademaker, 2004, p. 257) precisamente por su estilo. Sin embargo, como veremos en el siguiente apartado, es muy posible que este tipo de virtud aún no fuera valorada como tal en esos tiempos.

¿Qué conclusiones provisorias podemos sacar de todo este recorrido? Como nota Lloyd-Jones (1970, p. 10), en la historiografía parece haber una suerte de péndulo en torno a estos temas. Primero, predominaba la vieja mirada que consideraba la alusión a los dioses en los poemas homéricos como una mera forma de hablar, por lo cual estos no tenían una verdadera influencia en las elecciones de los hombres. ${ }^{20}$ Luego, la visión delineada por Nietzsche y desarrollada por Rohde -de la que se nutren Snell, Dodds y los aquí llamados "evolucionistas"-, pretende corregir el error del aquella mirada clásica, que negaba el énfasis de los rasgos irracionales del pensamiento griego, y así terminan por afirmar que los personajes homéricos no eran responsables por sus acciones y decisiones. Sin embargo, ahora el péndulo parece virar hacia el otro lado, de la mano de los autores que critican esta última línea exegética y

${ }^{19}$ Para ello adopta la perspectiva de la gramática cognitiva y la idea de categoría abierta, que supone que un término puede tener distintos sentidos conectados entre sí en distintas redes (networks). Así, analiza los diversos significados que presentan los términos en cuestión y cuáles prevalecen según el género textual y el autor analizado. El significado de un término lexical considerado de esta manera es un concepto cognitivo que es estructurado como una categoría abierta, con varios grupos de usos del término en cuestión, conectados entre ellos en una network por family resemblance; es una categoría centrada alrededor de uno o más prototipos (uso central); cada grupo tiene subcategorías en sí y probablemente exhiba un fenómeno de prototipicalidad y casos límite. (Rademaker, 2003, pp. 25-26).

${ }^{20}$ Esta línea interpretativa también tiene sus defensores modernos como M. Nilsson y P. Mazon (Lloyd-Jones, 1970, p. 10). 
ponen el énfasis, a veces demasiado excesivo, en las continuidades dentro de la ética griega. El problema es que, de esta manera, hacen de la moral algo ahistórico, y y aíslan el surgimiento de determinado tipo de concepción del ser humano de las condiciones históricas de las que necesariamente surge y sin las cuales es imposible comprenderla. $^{21}$

\section{(2) Enkrateia y sujeto moral}

Intentaremos ahora proponer una alternativa de análisis a las corrientes vistas en el apartado anterior. Veremos en particular una transformación que parece producirse en la moral griega en el siglo $\mathrm{V}$ a.C., alrededor de la cuestión del control de los placeres o enkrateia. Este concepto es particularmente fértil, debido a que en su mismo origen etimológico -el sustantivo kratos y el verbo krateō, que sugieren el control y la dominación sobre otros- se puede observar la relación profunda entre la política y la ética, es decir, entre el contexto histórico social y la moral que de desprende de este.

Como mencionamos en el apartado anterior, respecto de la enkrateia, ciertos autores de la línea continuista la consideran un aspecto central de la virtud griega a lo largo de toda la historia antigua (Rademaker, 2004, p. 251). Por otra parte, otros de la corriente que hemos llamado evolucionista consideran que el concepto de dominio de sí ha sido introducido por Sócrates y ha revolucionado la ética griega (Jaeger, [1933], p. 432; Mondolfo, 1960, p. 38). Al mismo tiempo, dentro de los estudios socráticos, que florecieron en las últimas décadas, este tema ha comenzado a estar en el centro de la escena (Dorion, 2003, 2007, 2018; Rossetti, 2008; Urstad, 2008; Danzig, en prensa). Dorion (2018, p. 154) afirma que es plausible la afirmación de Jaeger de que Sócrates haya sido el inventor de esta palabra, ya que encontramos esta idea por primera vez en los escritos de Platón y Jenofonte. Sin embargo, llama la atención sobre el hecho de que, paradójicamente, Platón en sus diálogos de juventud o socráticos, no utiliza en absoluto el léxico de la enkrateia. En particular, este autor deja de lado la llamada "cuestión socrática" por considerarla un problema insoluble y mal planteado (Dorion,

\footnotetext{
${ }^{21}$ Una crítica en este sentido realiza Eggers Lan (1967) a los animistas ingleses y también a sus críticos.
} 
2018, p. 155; Dorion, 2000, pp. XCIX-CXVIII; Dorion, 2011, pp. 1-23) y se encarga de descifrar esta ausencia en los diálogos platónicos. ${ }^{22}$ Estos trabajos se caracterizan tener una mayor especialización, y focalizarse en un filósofo o escuela filosófica particular, dejando de lado problemas más generales sobre la ética griega.

En este apartado veremos que la enkrateia es algo propio de la época clásica como planteaban los autores de la primera corriente analizada-. Sin embargo, que haya transformaciones entorno a la conceptualización de la moral y el ser humano, no significa que exista una evolución moral o fases más desarrolladas que otras. A su vez, veremos que no es un invento de un genio aislado de su tiempo, sino que fue verdaderamente un fenómeno de época, que comenzó a germinar en el siglo $V$ y continuó en el IV a. C. De esta manera, el análisis aquí provisto puede ser de utilidad para poner en contexto los estudios sobre las escuelas socráticas.

En particular, nos centraremos en la (pre)historia del concepto de enkrateia, esto es, cómo se fue conformando el concepto de "dominio de sí" o "autocontrol" (autou kratein), en los años previos a la aparición de la palabra misma enkrateia. ${ }^{23}$ Este sustantivo aparece por primera vez en la literatura del siglo IV a. C., con el sentido específico de dominio a sí mismo, autodominio. En los años previos a la sistematización de este concepto en la ética aristotélica (Ética Nicomaquea VII 1145a15-1154b35), sus apariciones son muy escasas. ${ }^{24}$ De allí podemos deducir que a lo largo del siglo IV a. C. este término estaba todavía acuñándose. Sin embargo, el concepto parece haberse gestado antes, a fines del siglo $\mathrm{V}$, a partir de la progresiva internalización del sentido del adjetivo enkratēs. Este último aparece por primera vez en las obras de Heródoto y Tucídides, y desde sus orígenes significaba, por un lado, "fuerte", y por otro "el que está en posesión de algo" o "el que controla o domina algo

${ }^{22}$ Explica la ausencia del léxico de la enkrateia en los diálogos tempranos de Platón, en primer lugar, debido a la negación de la akrasia de este período socrático de Platón (Dorion, 2006), y luego por la necesidad de una partición del alma al menos en dos partes para poder decir que una domina a la otra. (2017)

${ }^{23}$ Para un análisis más completo algunos de los casos aquí presentados, véase Lozano Nembrot

${ }^{24}$ Enkrateia aparece solo en ocho textos: veintiún apariciones dentro del corpus de Jenofonte (Ciropedia 1.2.8, 1.5.9, 7.5.76, 8.1.36-37, 8.8.15; Helénicas 5.3.21; Memorabilia 1.5.1, 1.5.4, 2.1.; 4.5.2, 4.5.8-9; Agesilao 4.3; 5.4), dos veces en la República de Platón (República 390b, 430a), una vez en Esquines el orador (Contra Timarco 181) y dos en Isócrates (A demónico 1.21; Nicocles 3.44). 
o alguien" (Danzig, en prensa, p. 2). ${ }^{25}$ Este último sentido en sus orígenes tenía solo un uso externo, esto es, se aplicaba a algo fuera del agente. ${ }^{26}$ Luego, se le añade uno nuevo, que llamaremos "interno", para referirse a alguien que se controla o domina a sí mismo. Estos son dos usos -no dos sentidos-, ya que no varía el significado del término, que refiere al control o dominio sobre algo, sino a qué se aplica.

El único testimonio del siglo $\mathrm{V}$ en que propiamente se utiliza este adjetivo de forma interna es un fragmento del Anónimo de Jámblico, presunto sofista del siglo $\mathrm{V}^{27}$ Sin embargo, es posible encontrar otros testimonios relevantes de este período -es decir, previos al siglo IV a.C.--, en donde este uso anímico es anticipado. Para ello, es necesario analizar no solo el adjetivo enkratēs, sino también los términos de los que se ha originado, el verbo krateō y el sustantivo kratos. Veremos aquí brevemente cómo este vocabulario comienza poco a poco a aplicarse al terreno anímico en los distintos ámbitos del clima intelectual del siglo V.

(1) En primer lugar, en el terreno de la tragedia, hallamos las primeras aproximaciones de un uso psicológico de enkratēs y sus cognados. En las obras de Esquilo, primero de los tres grandes tragediógrafos, no encontramos ningún caso relevante. Pero sí en las de Sófocles, en tres obras distintas. En Antígona utiliza enkratēs dos veces con el sentido de "fuerte", una para referirse al hierro (v. 471) ${ }^{28} \mathrm{y}$ luego como adverbio ("sostener fuertemente las escotas" v. 715) ${ }^{29}$. Lo interesante es que en ambos casos aparece en una analogía con el carácter obstinado de Antígona en boca de Creonte- y luego de Creonte -en boca de su hijo Hemón- respectivamente.

${ }^{25}$ LSJ u.v. enkratēs. De todas formas, ambos sentidos están relacionados entre sí: el control sobre algo deriva de la fuerza del agente. Según Chantraine, todas las palabras que analizaremos en este apartado provienen del sustantivo kratos, que significa "fuerza", primariamente fuerza física que permite triunfar, y de allí "victoria, poder, soberanía" (Chantraine, 1968, p. 578 u.v. kratos).

${ }^{26}$ Heródoto, Historias 8.49, 9.106; Tucídides, La guerra del Peloponeso 1.76.

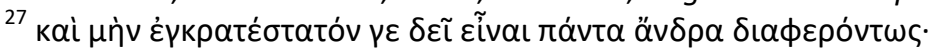

Hablando sobre la búsqueda de riquezas y el aferrarse demasiado a la vida, afirma que "es necesario que todo hombre sea el más enkratēs (ejerza completamente un dominio sobre sí)". Tanto la traducción al español (Bellido Gredos) como la del italiano (Ursteistainer) traducen "que ejerza un dominio sobre sus pasiones" asumiendo este sentido de enkratēs. Otra alternativa sería pensar que se refiere a la fuerza del carácter, pero no en relación con las pasiones (similar a los pasajes de Antígona de Sófocles que veremos a continuación).

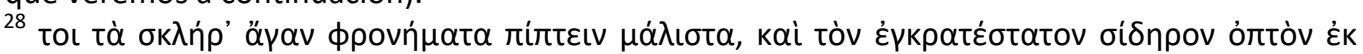

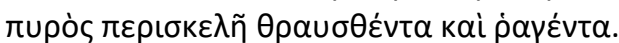

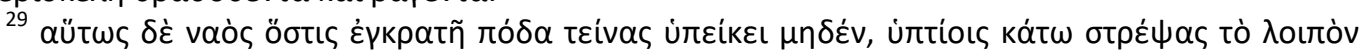

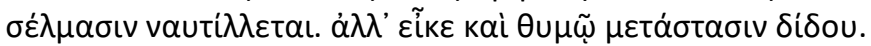


Por otra parte, en Edipo en Colono $(405)^{30}$ y Ayax $(1099)^{31}$ se utiliza la expresión autou kratein para referirse al no ser dominado por otra persona. Este caso no supone aún una interioridad reflexiva, pero es relevante debido a que precisamente este sentido de no ser dominado por otro será luego el que se traspasa al interior anímico para referirse a ese otro interior que son las pasiones.

Luego, Eurípides, autor inmerso en el clima intelectual del siglo $\mathrm{V}$, dará un paso más con las famosas palabras finales de Medea vv. 1075-1080 "Entiendo ciertamente qué clase de males voy a realizar, pero mi thymos (pasión, impulsividad) es más fuerte que (gobierna sobre) mis deliberaciones (boulēmata), y él es el causante de los mayores males para los mortales" ${ }^{32}$. Aquí se aplica kreissōn (el adjetivo comparativo) al thymos, elemento ciertamente de orden psíquico, que domina sobre otros aspectos anímicos.

(2) En segundo lugar, en el ámbito de la sofística y la oratoria del siglo $\mathrm{V}$ también se comienza a utilizar este tipo de expresiones. Además del pasaje mencionado de Anónimo de Jámblico, encontramos otros significativos. Por un lado, Antifonte el orador hace uno de autou kratein para referirse a un hombre que no era dueño de sí mismo porque estaba borracho, ${ }^{33}$ lo cual constituye un paso más en el camino hacia una utilización propiamente psicológica de este tipo de palabras. Por otra parte, hay un punto de inflexión fundamental en ciertos pasajes de Antifonte el sofista (DK B 58) $)^{34}$ y Gorgias (Defensa de Palamedes DK B 11a15) ${ }^{35}$, quienes utilizan este tipo

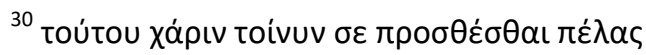

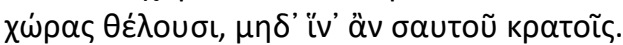

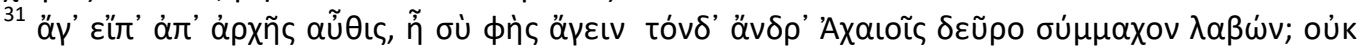

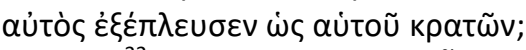

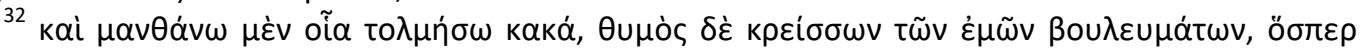

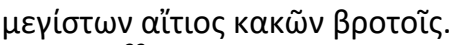

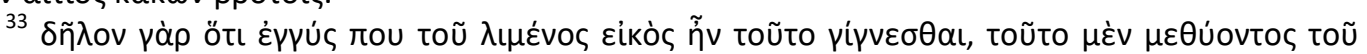

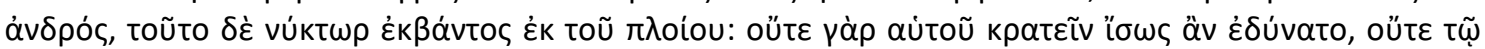

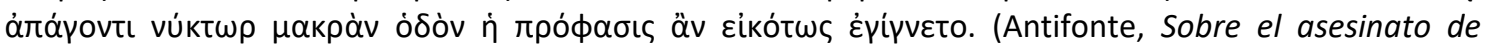
Herodes 26).

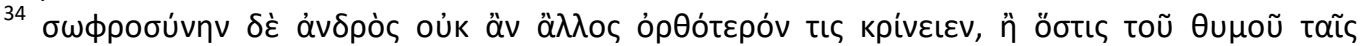

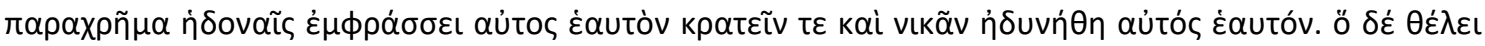

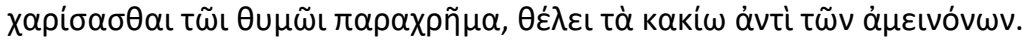

"Ningún otro podría juzgar más correctamente la prudencia (sōphrosynē) de un hombre que quien se protege de los placeres inmediatos de la pasión (thymos), el mismo que es capaz de dominarse a sí mismo y vencerse a sí mismo. Quien, por el contrario, quiere satisfacer la pasión inmediata, quiere lo peor antes que lo mejor." (La traducción es nuestra) 
de expresiones relacionándolas específicamente con el dominio de los placeres. Se marca aquí una oposición, que será clave luego en autores posteriores como Jenofonte, entre el que es esclavo de los placeres y desea permanentemente satisfacer la pasión inmediata, y aquel que se domina a sí mismo, esto es, controla sus pasiones y deseos. Además, en el fragmento de Antifonte sofista, se asocia a este hombre con la sōphrosynē, palabra mucho más antigua que la enkrateia, pero que a partir del surgimiento de esta última, en es común encontrarla asociada de una manera u otra a aquella.

(3) En tercer lugar, esta misma antítesis la encontramos en el terreno filosófico en los textos éticos del atomista Demócrito, en DK B 214: "Valiente no es sólo el que domina a los enemigos, sino el que domina a los placeres (ho tōn hedonōn kressōn). Pero algunos son amos de ciudades (políōn men despozousi), pero esclavos de mujeres (gynaixi de douleuousin)." ${ }^{36}$ Por otra parte, este concepto es de tal importancia en la ética de todos socráticos, que muchos intérpretes deducen que Sócrates pudo haber sido el inventor de este término (Jaeger, 2016 [1933], p. 432; Mondolfo, 1960, p. 38; 1962; Rossetti, 2008). De hecho, estos autores ponen a Sócrates como la figura bisagra entre lo que era la moral tradicional, basada en la inevitabilidad de las pasiones, y la moral basada en el dominio de los placeres. Sin desestimar esta visión ni el importante rol que Sócrates y sus discípulos tuvieron en el desarrollo de este concepto, el breve recorrido aquí realizado pone en contexto esta noción que Sócrates pudo haber adoptado como propia.

De esta forma, a partir del análisis realizado, notamos, en primer lugar, que en el siglo $\mathrm{V}$, al menos en el ambiente intelectual, comenzó a emplearse la familia de palabras de krateō y enkratēs, que antes se utilizaban solo para referirse al dominio de algo externo, para referirse al ámbito anímico. Es el mismo sentido del control sobre

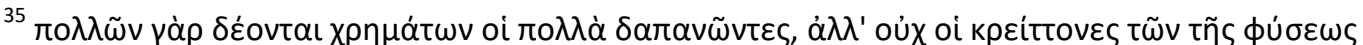

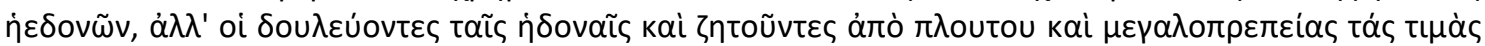

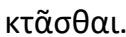

"Pues mucho dinero necesitan los que mucho gastan, pero no los que dominan los placeres naturales, sino los que son esclavos de los placeres y buscan desde el dinero y la magnificencia adquirir honores." (La traducción es nuestra)

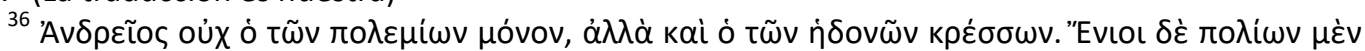

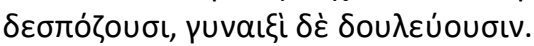


algo que se repliega sobre sí mismo y pasa a transmitir la idea de autodominio. El dominio de uno mismo es en verdad el de una parte de sí específica que son los placeres (tōn hedonōn) o la impulsividad, la pasión (ho thymos). Vemos entonces que los placeres son incorporados como una parte del yo, y ya no son considerados como una fuerza que proveniente del exterior y por tanto inevitable. ${ }^{37}$ Es decir, se genera una reflexividad, una relación consigo mismo -un pliegue, como veremos que dirá Deleuze- que no encontramos en los siglos anteriores. A su vez, esta nueva virtud del control de los placeres se asocia en este momento con la sōphrosynē, palabra mucho más antigua y con un gran abanico de significados, ${ }^{38}$ que denotaba la cualidad del carácter que lleva a un buen comportamiento (Danzig, en prensa, p. 9). Proponemos aquí que en estos siglos (V y IV a .C.) a estos múltiples significados se le añade como uno que será fundamental, el dominio de sí mismo. En segundo lugar, advertimos que este nuevo concepto no es un invento repentino de Sócrates, como afirman los autores mencionados, ${ }^{39}$ sino que es producto del clima intelectual del siglo V: se puede observar este nuevo lenguaje en la tragedia, el ambiente sofístico y retórico, y hasta en el filósofo atomista Demócrito.

El origen aquí analizado del dominio de sí mismo a partir de la dominación de los otros se observa en el desarrollo de este concepto en las filosofías del siglo IV a. C. Esto se manifiesta especialmente en las escuelas socráticas, donde la ética y la política están fuertemente entrelazadas. A pesar de las diferencias respecto del manejo de los placeres que profesan Jenofonte y Aristipo, ambos acuerdan en que la enkrateia es una característica que todo gobernante debe poseer (Memorabilia 2.1). Sin embargo, cada socrático ha dado una significación distinta a esta cualidad. Aristipo, hedonista extremo, propone una enkrateia particular que supone poder disfrutar de los placeres pero sin ser dominado por ellos (FS, 409 = Diógenes Laercio, II.78 [Arsenio, 112.10-5] = SSR, IV.A.31; FS, 476 = Diógenes Laercio, II.67 [Arsenio, 113.3-79] = SSR IV.A.86; Urstad,

${ }^{37}$ Como todo proceso histórico, este cambio no se produce de un momento para el otro, sino que la nueva concepción del ser humano y sus pasiones convive con la anterior, que tendía a exteriorizar y personificar a las pasiones, considerándolas inevitables, la cual la podemos encontrar incluso en oradores del siglo IV a.C. (Rossetti, 2008; Lozano, 2018).

${ }^{38}$ Para un análisis diacrónico de estos significados véase North (1966) y para uno sincrónico de los diversos sentidos de este término en el siglo IV a. C. véase el ya mencionado Rademaker (2004).

${ }^{39}$ Véase supra pp. 190-193. 
2008, p. 5; Illarraga, 2018, p. 5). ${ }^{40}$ En cambio, Jenofonte, probablemente influido por la filosofía de Antístenes, ${ }^{41}$ si bien no sostiene una abstención total de los placeres, advierte sobre la peligrosidad intrínseca de estos, y coloca a la enkrateia, considerada como dominación y contención de los placeres, como el fundamento de la virtud (Memorabilia 1.5.4; Dorion, 2003; Danzig, forthcoming). Por otra parte, aunque, como marca Dorion (2007; 2018), en Platón el uso de esta palabra es mucho más modesto, el dominio de los placeres es tematizado y ocupa un lugar importante en diálogos medios y de vejez (Banquete 188a; Gorgias 491d; Fedro 256b; República 390b, 430e, 605b; Leyes $645 \mathrm{e}, 839 \mathrm{~b}, 840 \mathrm{c}, 966 \mathrm{e})$. Por último, el tratamiento de la enkrateia y su opuesto, la akrasia, es sistematizado por Aristóteles, especialmente en el libro VII de la Ética Nicomaquea, donde provee la definición específica del hombre enkratēs como el que que sabe resistir a sus deseos (Ética Nicomaquea 1151b35-1152a5).

\section{(3) Foucault, Deleuze y los pliegues de la subjetivación}

Para finalizar, a modo de epílogo del presente artículo, relacionaremos este recorrido con la filosofía foucaultiana. Foucault lee a los griegos desde su propia filosofía, la cual constituye una alternativa al modo de acercamiento de las corrientes estudiadas en el primer apartado, y nos puede permitir ampliar la propuesta de estudio que hemos esbozado aquí para investigar la enkrateia como un fenómeno de los siglos V y IV a. C. Esto es debido a que el análisis foucaultiano se basa en tres ejes que pueden observarse en cada momento histórico: las relaciones de saber, las relaciones de poder y la ética o las subjetivaciones, los cuales no se dan independientemente sino imbricados unos con otros (Foucault, 2013 [1994], p. 135; Deleuze, 2015 [1986], p. 141). Entonces, veremos el surgimiento de la enkrateia como algo que depende de las relaciones de poder y de saber predominantes en la Grecia Clásica, pero que logra

\footnotetext{
${ }^{40}$ FS (“Fragmento Socrático") se refiere al número fragmento de la completa compilación sobre socráticos realizada por C. Mársico (2013a; 2013b).

${ }^{41}$ Para Antístenes y luego la escuela cínica la enkrateia consistirá en una abstención total de los placeres (FS 766 = Diógenes Laercio, VI.13-5 = SSR, V.A.22; FS 781 = Diógenes Laercio, VI. 103-5 = SSR, V.A.135; FS 991 = Diógenes Laercio, VI.8-9 = SSR, V.A.172).
} 
adquirir cierta autonomía. Esto permite comprender, sin presuponer un desarrollo histórico lineal, la relación entre la realidad social y política y la ética de este momento determinado.

Con el segundo volumen de Historia de la Sexualidad: El uso de los placeres (1984), se produce un giro en la filosofía foucaultiana. ${ }^{42}$ Aquí, y en los cursos que dictará en los últimos años de su vida, el filósofo francés realiza un regreso a los antiguos, y en particular hacia el terreno de la ética. ${ }^{43}$ En el libro mencionado, Foucault se propone hacer una genealogía del hombre de deseo, ya que -como expuso previamente en el primer volumen, La voluntad de saber- el deseo no es algo dado naturalmente, sino un elemento del discurso cristiano y moderno. Por tanto, el objetivo es descifrar cómo se ha configurado la sexualidad como "experiencia", entendida como la correlación dentro de una cultura entre campos de saber, tipos de normatividad y formas de subjetividad (Foucault, 2013 [1984], p. 10). ${ }^{44}$ Como dice Halperin (1990), Foucault pretende hacer con el deseo lo que Nietzsche hizo con el bien y el mal. ${ }^{45}$

Pero para escapar de la noción sexualidad propia de la modernidad y del psicoanálisis, que la coloca como el fundamento de la identidad de cada persona, Foucault debe remontarse al mundo grecorromano. ${ }^{46}$ Para su abordaje adopta una forma particular de concebir la moral: no como un código o conjunto prescriptivo de valores y reglas de acción de determinada sociedad (el "código moral"); ni como

${ }^{42}$ Véase Foucault (2013 [1984], p. 12); Deleuze (2015 [1986], p. 171).

${ }^{43}$ Se han hecho varias críticas a la lectura de Foucault de los antiguos: desde la coherencia con su filosofía anterior (Cohen, D., Saller, R. 1994); desde el feminismo (P. duBois, 1998); y también desde los especialistas en filosofía antigua (Davidson, 2001). No nos meteremos aquí en el análisis específico de los textos, sino que veremos la proyecto general de Foucault a la hora de estudiar a los antiguos, que consideramos valioso como punto de partida hermenéutico.

${ }^{44}$ Estos son los tres ejes mencionados del pensamiento foucaultiano: el saber, el poder y la subjetividad o la ética.

${ }^{45}$ Foucault señala que él no hace una genealogía de la moral -ya que los códigos morales son relativamente estables a lo largo de la historia de occidente-, sino una genealogía de la ética, entendida como la relación del sujeto consigo mismo. "La genealogía del sujeto como sujeto de las acciones éticas o la genealogía del deseo como problema ético" (Foucault, 2013 [1994], p. 140).

46 “... después de escribir el primer volumen de su historia, Foucault eventualmente se dio cuenta de que mientras siguiera escribiendo sobre sexualidad, seguiría jugando el juego de Freud, el juego psicoanalítico de verdad que él venía tratando de escabar y venía criticando por décadas (...) Lo que Foucault vio fue una alternativa a la sexualidad (...) por donde pudiera ser posible transformar o improvisar a uno mismo inventando o imaginando una identidad aparte de la sexualidad." (Black, 1998, pp. 46-47, la traducción del inglés es nuestra). 
"moralidad de los comportamientos", es decir, la conducta real de los individuos en relación con esas reglas; sino como determinada relación consigo mismo, la constitución del sujeto moral o la "sustancia ética", esto es, la parte de sí mismo que el individuo constituye como el objeto de la práctica moral (Foucault, 2013 [1984], pp. 31-32; Foucault, 2013 [1994], p. 135). Este enfoque nos brinda una interesante alternativa a la visión kantiana sobre la moralidad predominante en los estudios clásicos, así como a la línea interpretativa de corte analítico. Y, en efecto, es particularmente atractiva para analizar las éticas antiguas, debido a que estas se caracterizaban por una "ausencia raigal de parámetros" en todos los ámbitos (Mársico, 2011). Foucault afirma que en la antigüedad las personas no se basaban en un código fijo de reglas como lo hacen otras culturas, ${ }^{47}$ sino que las reflexiones morales grecorromanas se orientaron "más hacia las prácticas de sí y la cuestión de la askēsis que hacia las codificaciones de conductas y la definición estricta de lo permitido y lo prohibido" (Foucault, 2013 [1984], p. 37). ${ }^{48}$

Desde aquí, Foucault sistematiza la moral griega de esta forma: el concepto fundamental es es el uso de los placeres (chrēsis aphrodisiōn), esto es, la forma en que el individuo dirige su actividad sexual -así como otros placeres-, a través de una actitud particular que es la enkrateia, el dominio de sí, para llegar al telos moral que consiste en la sophsosyne, la templanza caracterizada como una libertad activa. ${ }^{49}$ De esta manera, Foucault descubre en los antiguos algo que le interesa más que la sexualidad: ${ }^{50}$ una forma particular de relacionarse consigo mismo, alternativa a la hermenéutica del deseo propia del cristianismo y la modernidad, que coloca en el sexo una exigencia de verdad que promete revelar la realidad de lo que somos (Foucault, 2016 [1976], p. 75). En el caso de la Grecia Clásica, estudiada en este libro, esta relación con uno

$47 \mathrm{Si}$ bien siempre están presentes los tres elementos -código moral, moralidad de los comportamientos y relación consigo mismo- en determinadas culturas suele primar más uno que el otro.

${ }^{48}$ Como remarca A. I. Davidson (1997), el estudio del filósofo francés sobre comportamiento sexual de los antiguos está guiado por la noción de Hadot de "ejercicio espiritual", que Foucault relaciona con las prácticas de sí y el ejercicio de gobernarse a sí mismo.

${ }^{49}$ Esto es desarrollado en detalle en el primer capítulo de El uso de los placeres (Foucault, 2013 [1984], pp. 39-105).

50 "Debo confesar que me intereso mucho más por los poblemas planteados por las técnicas de sí o las cosas de ese tipo que por la sexualidad... iLa sexualidad es aburrida!" (Foucault, 2013 [1994], p. 123). 
mismo se da bajo la forma de la enkrateia o dominio de sí. Esta tiene un modo agonístico, es una forma activa de dominio sobre sí que permite resistir o luchar, y asegurar su dominio en el campo de los deseos y los placeres. Este estado de virtud no implica la supresión de los apetitos sino su dominio, y por tanto la virtud es una relación de dominación, de control.

Podemos reforzar esta idea con el análisis realizado en el segundo apartado sobre origen del uso psicológico de esta palabra, en cuyos orígenes significaba el dominio de los demás. Es el mando sobre los otros lo que se vuelve sobre sí mismo para controlar ese otro inferior interno que son los placeres. $Y$ es precisamente esta condición lo que permitirá legítimamente regir a los demás. Es decir, se produce primero un movimiento del gobierno de los otros al gobierno de sí, para luego pasar nuevamente a la exterioridad y al dominio sobre el resto. Este pasaje es visible en el Alcibíades I de Platón, en donde Sócrates interviene en la vida de Alcibíades en el momento en que este pretende actuar en política, para recordarle que para gobernar bien es necesario primero conocerse y dominarse a sí mismo (124b y ss.; 134c; 135d). También Jenofonte en Memorabilia 2.1. presenta a Sócrates discutiendo con Aristipo sobre los requisitos de un buen gobernante, y ambos acuerdan en que el dominio de los placeres es lo fundamental. Para lograr esto, como remarca Foucault, es necesario el apoyo de una askēsis, un ejercicio continuo que supone el cuidado de uno mismo (epimeleia heautou). A partir de este ejercicio es que se puede llegar al telos moral que es la sōphrosynē, la templanza o moderación, entendida como ser libre o no ser esclavo de los placeres. El poder que ejercemos sobre nosotros mismos es el poderío que ejercemos sobre los otros, el que debe dirigir a los demás tiene que ser capaz de una autoridad perfecta sobre sí mismo (Foucault, 2013 [1984], p. 90). Vemos aquí la estrecha relación, que Foucault profundizará en los cursos del College de France, entre el gobierno de sí y el de los otros, entre la ética y la política. ${ }^{51}$

Esta problemática se puede apreciar especialmente en la lectura que hace Deleuze, influida fuertemente por la filosofía nietzscheana. En sus cursos sobre su colega francés -así como en el libro después publicado (Deleuze, 2008 [1986]; 2015

${ }^{51}$ Foucault $(2001 ; 2008)$. 
[1986])-, Deleuze retoma el concepto de enkrateia y lo coloca en el centro del último período de la filosofía foucaultiana. El "diagrama griego" -cómo se organizan las fuerzas en determinado momento de la historia- supone agentes libres con relaciones agonísticas entre ellos: solo estos pueden dominar a los demás. Entonces, para definir entre ellos quién debe gobernar, el criterio será "el que se gobierna a sí mismo". Así, la dominación de los otros se pliega hacia el dominio sobre sí, generando una reflexividad o una relación uno mismo. Esto permite que la fuerza -que hasta ese momento solo podía actuar sobre otra fuerza- actúe sobre sí misma, generando un pliegue a partir de la exterioridad, y esto abre por primera vez un espacio de interioridad. Esto es lo que vimos plasmado en el proceso de gestación del uso psicológico de estos términos.

De esta manera es que se produce por primera ves un tipo de subjetivación. Y esta es la respuesta de por qué volvemos permanentemente a los griegos: ellos han inventado el sujeto. ¿Es posible que al llamar "sujeto" o "subjetivación" a este movimiento que realizaron los griegos Foucault y Deleuze impongan una categoría propiamente moderna a los antiguos griegos? Quizás en parte sí. Sin embargo, esto no necesariamente constituiría una objeción para ellos, ya que, como filósofos, su estudio de los griegos está explícitamente condicionado por sus propias pretensiones filosóficas. Desde este lugar de enunciación, propio de la filosofía contemporánea, no pretenden un discurso de verdad sobre los griegos, sino un relato que permita conectarlos -sea como contrapunto o como origen de ciertas problemáticas- con nuestro presente. Por otra parte, lo interesante de la propuesta de la lectura foucaultiana-deleuziana es que lo que observan en los griegos es un sujeto que no es una sustancia fundante como el moderno, sino que es siempre derivado de la relación con lo exterior. Por ello más que un sujeto es un modo o proceso de subjetivación, un modo de relacionarse consigo mismo. Esta subjetivación no es única, sino que existen diversos modos de plegado. La sexualidad es una forma posible, quizás la más inmediata, en que actualiza el pliegue, pero puede haber otras.

La idea fundamental de este momento de la filosofía foucaultiana, según Deleuze, es la de una dimensión de la subjetividad que deriva del poder y del saber, 
pero que no depende de ellos. En consecuencia, este nuevo eje es la fuente de puntos de resistencia y de apertura de potencialidades. La relación consigo mismo es el lugar decisivo de articulación entre las tecnologías de poder y las prácticas de resistencia (Foucault, 1984, p. 254). ${ }^{52}$ O, en palabras de Deleuze, a partir de las reglas obligatorias del poder se doblan las "reglas facultativas" del hombre libre, entendidas como funciones reguladoras que se distinguen de los códigos, ya que no son una obligación sino una decisión. Es necesario que de los códigos morales se libere un sujeto que rompa con ellos, que no dependa de esas reglas fijas en su parte interior. Los griegos han descubierto así el doblez de la relación consigo mismo o una "estética de la existencia".

Foucault, como buen nietzscheano, presenta la askēsis en conjunción con la aisthēsis, la historia de la ética es también estética. ${ }^{53}$ Foucault define la estética de la existencia como

una manera de vivir cuyo valor moral no obedece ni a su conformidad con un código de comportamiento ni a un trabajo de purificación, sino a ciertas formas o más bien a ciertos principios formales generales en el uso de los placeres (Foucault, 2013 [1984], p. 100).

Al remontarse a la cultura antigua encuentra que la problematización de los placeres está ligada a las "artes de la existencia" o "técnicas de sí": prácticas sensatas y voluntarias por las que los hombres no sólo se fijan reglas de conducta, sino que buscan transformarse a sí mismos, modificarse en su ser singular y hacer de su vida una obra que presenta ciertos valores estéticos y responde a ciertos criterios de estilo (Foucault, 2013 [1984], p. 17). Lejos está esta perspectiva del punto de vista kantiano, que coloca al deber como única noción relevante para la ética. En una entrevista (Foucault, 2013 [1994], p. 126), Foucault se pregunta si nuestro problema hoy no es

\footnotetext{
52 Es precisamente la noción de "gobierno" el punto de contacto donde se ve cómo la manera en que los individuos son dirigidos por otros se articula con cómo se conducen a sí mismos.

53 Esta unión termina abruptamente en el siglo XVIII, donde los discursos sobre sí son reinsertados en las ciencias humanas. Allí el sujeto deja de estar preocupado por el cultivo de sí, se cree libre y de esta manera permite ser subjetivado y objetivado por las emergentes ciencias humanas (Black, 1998, p. 53). Por otra parte, este tipo de discurso comienza con la filosofía moderna, más específicamente con Descartes: "Pero lo extraordinario de los textos de Descartes es que logró sustituir un sujeto constituido gracias a las prácticas de sí por otro fundador de prácticas de conocimiento (...). La evidencia sustituye a la ascesis en el punto de unión entre la relación consigo mismo y la relación con los otros, la relación con el mundo." (Foucault, 2013 [1994], pp. 156-157).
} 
similar al de los griegos, cuya moral no estaba ligada a un sistema institucional, social o legal, sino que el objetivo era constituir una estética de la existencia. ${ }^{54}$ Tal vez esto mismo podría aplicarse hoy en día, que ya son pocos los que creen que una moral pueda fundarse en la religión y tampoco es fácilmente aceptado que el sistema legal intervenga en nuestra vida personal. Frente a esta situación, no es fácil encontrar un principio sobre el cual fundar una nueva moral. ${ }^{55}$ Una posible respuesta es, como los griegos, intentar hacer de nuestra existencia, de nuestro modo de vida, una obra de arte.

\section{Conclusiones}

A partir del recorrido realizado, se han desplegado una serie de complejos interrogantes sobre el estudio de la antigüedad. En primer lugar, la problemática de los cambios y continuidades dentro de la moral griega. Luego de relevar las principales corrientes respecto de este tema en el primer apartado, en el segundo hemos propuesto un posible punto de partida, el desarrollo del concepto de la enkrateia o dominio de sí. El interés por este modo de comportamiento, su expresión en el lenguaje y su conceptualización comienzan en el siglo $\mathrm{V}$ a.C. y continúan su desarrollo en el IV, cuando aparece por primera vez la palabra enkrateia. Sin apelar a una teleología o suponer que hay fases más evolucionadas que otras, sí podemos notar una clara transformación en la moral griega, que coloca en el centro de la escena el problema del dominio de los placeres, considerados como una parte del yo que hay que controlar.

En segundo lugar, ha aparecido el problema de los presupuestos filosóficos de los estudios sobre la antigüedad y la relación que podemos establecer entre los griegos

${ }^{54}$ Deleuze (2015 [1986]), p. 139) agudamente remarca que la resistencia hoy es el derecho a la diferencia y a la variación, a la metamorfosis, contra la individuación del poder y contra la identidad fija determinada. Esto parece aún más vigente hoy en día, sobre todo si pensamos en los recientes cambios que se están produciendo en torno a los movimientos feministas y LGBT.

${ }^{55}$ Como afirma Mársico (2011, p. 15), la marca griega es la de una verdad frágil e inestable, y la contemporaneidad parece hallarse en un momento similar. "Esta coincidencia basta para hacer de los orígenes de este estado de inestabilidad un campo curioso con natural potestad para despertar la atención de sujetos en desamparo similar al de esos antiguos griegos." 
y el presente del historiador de la filosofía antigua. Hemos examinado los presupuestos filosóficos de los estudios clásicos sobre la moral griega, la primera corriente basada en filosofías modernas y la segunda en teorías contemporáneas anglosajonas. Como alternativa a ambas, hemos considerado la teoría foucaultiana sobre estos temas, que parte desde un punto de vista genealógico nietzscheano. Más allá de las cuestiones específicas que puedan criticarse, Foucault da un aire novedoso a estos temas, ya que no se acerca a la antigüedad de la manera en que lo hacen los especialistas en filosofía antigua. ${ }^{56}$ Por ello, no se centra en los detalles de cada filósofo o cada género, sino que proporciona una mirada general de la moral antigua clásica y la utiliza para pensar su propia filosofía y la ética hoy en día. A su vez, su pensamiento situado e interesado filosóficamente hace que no tenga una pretensión de verdad absoluta sobre los griegos, sino que los utiliza para pensar alternativas a las éticas propias de la modernidad. Desde aquí, propone pensar a la moralidad griega como una determinada relación consigo mismo, que en cierto momento, debido a determinadas condiciones históricas particulares -a ciertas relaciones de saber y de poder-, tomó la forma del dominio de sí o enkrateia. Hemos visto aquí cómo comienza a aparecer esta noción en el siglo $V$ a. C. a partir de una nueva reflexividad del adjetivo enkratēs y sus cognados. De esta manera, podemos poner en contexto el análisis sincrónico que realiza el filósofo francés, y sacar a la luz esta noción como una novedad de estos siglos.

Para concluir, proponemos que los griegos y su forma de pensar al ser humano pueden servir, por un lado, como un otro a partir del cual desnaturalizar ciertas formas de la cultura vigente. ${ }^{57}$ En este sentido, para intentar comprender verdaderamente esa otredad, debemos insertarla dentro de las condiciones históricas y culturales de su surgimiento, para poder apreciarla en todo su esplendor. Pero al mismo tiempo, dado que nos encontramos en el terreno filosófico, también podemos jugar a abstraernos de las circunstancias particulares, para poder observar los puntos de encuentro que

56 Como remarca Halperin (1990), Foucault no trata de hacer lo que hacen los scholars tradicionales -a pesar de las reacciones de estos a su libro-, sino lo que no hacen.

${ }^{57}$ Esto es claro, por ejemplo, con el tema de la sexualidad, donde los griegos se pensaban de formas muy distintas a las nuestras, ajenas al binarismo en torno al objeto sexual. 
podamos tener con los antiguos. ${ }^{58}$ No desde el lugar tradicional de considerar a los griegos como el origen de la civilización occidental, sino haciendo hincapié en ciertos rasgos de esa realidad griega inestable que los asemejan a la sociedad contemporánea y permiten conectarnos con ellos.

\section{Bibliografía}

1. Adkins, A. W. H. (1960). Merit and Responsability. Oxford, Oxford University Press.

2. Alamillo, A. (1981). Sófocles, Tragedias. Madrid: Gredos.

3. Berthold, W (2003). Participación y personalidad. En Anuario Filosófico, $X X X V I / 1,247-269$.

4. Bieda, E. (2006). Medea, madre enfurecida: sobre los alcances del thymos en la Medea de Eurípides. En Juliá, V. (ed.), La tragedia griega, Buenos Aires, La isla de la luna, 2006, 85-98.

5. Black, J. (1998). Taking the sex out of sexuality: Foucault's failed history. En Larmour D. H. J., Allen Miller, P. (eds.). Rethinking Sexuality: Foucault and Classical Antiquity. Princeton: Princeton University Press.

6. Boehringer, S. (en prensa). Historia de la construcción de la identidad sexual en la Antigüedad griega y romana, trad. Diana Calzaretto y Luis Tamayo. En Conferencia Sexo, género y reótica: la comparación erótica en la Grecia antigua, Instituto de Filología Clásica de la FFyL UBA.

7. Boehringer, S. (2018). Chapitre II. En Grèce. En Steinberg, S. (ed.). Une histoire des sexualités. París: Puf.

8. Burnet, J. (1900-7). Platonis opera: recognovit brevique adnotatione critica instruxit. Oxford: Oxford Classical texts.

${ }^{58}$ De manera similar, Soares (2000, p. 116) propone el método de Hölderling para acercarse a la antigüedad, el cual consiste en "mirarse en los griegos como en un espejo que, en tanto que nos hace vernos en un otro, nos devuelve un reflejo renovado de nosotros mismos". Volver a los griegos críticamente sería entonces escuchar su mensaje desde nuestra contemporaneidad. 
9. Chantraine, P. (1952). Le divin et les dieux chez Homère. Fondation Hardt. Entretiens sur l'antiquit'e classique, Tome I: La notion du divin depuis Homère jusqu'à Platon Divin, 47-97.

10. Chantraine (1968). Dictionnaire Étymologique de la Langue Grecque. Paris: Éditions Klincksieck.

11. Cohen, D., Saller, R. (1994). Foucault on Sexuality in Greco-Roman Antiquity. En Jan Goldstein (ed.), Foucault and the Writing of History. Oxford: Blackwell.

12. Danzig, G. (en prensa). Enkrateia and Soprhosune in Xenophon. En 1o USP Xenophon International Colloquium, Sao Paulo 2017.

13. Davidson, J., (2001). Dover, Foucault and Greek Homosexuality: Penetration and the Truth of Sex. Past \& Present, No 170, 3-51.

14. Deleuze, G. (2008 [1986]). Foucault. Buenos Aires: Paidós.

15. Deleuze, G. (2015 [1986]). La subjetivación: curso sobre Foucault, Buenos Aires: Editorial Cactus.

16. Dodds, E. (1960 [1951]). Los griegos y lo irracional. Trad. Maria Araujo. Madrid: Revista de Occidente.

17. Dorion, L-A. (2003). Akrasia et enkrateia dans les Mémorables de Xénophon, Dialogue, vol. 42, n 04, 645-672.

18. Dorion, L-A. (2018). Enkrateia et partition de l'âme chez Platon, Revue de Philosophie Ancienne, XXXVI (2), 153-2013.

19. Dorion, L. A. (2007). Plato and enkrateia. En Ch. Bobonich y P. Destrée (eds.), Akrasia in Greek Philosophy (pp. 119-138). Leiden: Brill.

20. Dover, K. J. (1974). Greek Popular Morality in the time of Plato and Aristotle. Oxford: Basil Blackwell.

21. Dover, K. J. (1978): Greek homosexuality, Cambridge: Harvard University Press.

22. duBois, P. (1998). The subjetc in antiquity after Foucault. En Larmour D. H. J., Allen Miller, P. (eds.). Rethinking Sexuality: Foucault and Classical Antiquity. Princeton: Princeton University Press.

23. Eggers Lan, C. (1967). El concepto de alma en Homero. Buenos Aires: Facultad de Filosofía y Letras de la Universidad de Buenos Aires. 
24. Fierro, M.A. (en prensa). Fedro. Buenos Aires: Colihue.

25. Foucault, 2013 [1994]. La inquietud por la verdad. Buenos Aires: Siglo XXI.

26. Foucault, M. (1970). Historia de la sexualidad: la voluntad de saber, trad. M. Guiñazú. México: Siglo XXI.

27. Foucault, M. (2005): La hermenéutica del sujeto, Cursos en el College De France (1981-1982). Móstoles: Akal.

28. Foucault, M. (2009). El gobierno de sí y de los otros, trad. H. Pons. Buenos Aires: Fondo de cultura económica.

29. Foucault, M. (2013 [1984]). Historia de la sexualidad: El uso de los placeres, trad. M. Soler. Buenos Aires: Siglo XXI.

30. Fränkel, H. (1993 [1962]). Poesía y Filosofía de la Grecia Arcaica, trad. R. Sánchez Ortiz de Urbina. Madrid: Visor.

31. Gill, Ch. (1996). Personality in Greek Epic, Tragedy, and Philosophy. Oxford: Clarendon Press.

32. Guzmán Guerra, A. (1989). Tucídides, Historia de la Guerra del Peloponeso. Madrid: Alianza.

33. Halperin, D. M. (1990). One hundred years of homosexuality: And other essays on Greek love. New York: Routledge.

34. Hegel, G. W. F (2009 [1807]). Fenomenología del espíritu. Trad. M. Jiménez Redondo. Valencia: Pre-Textos.

35. Hubbard, T. K. (ed.) (2003). Homosexuality in Greece and Rome: A sourcebook of basic documents. Berkeley: University of California Press.

36. Illarraga, R. (2018). Enkráteia y gobierno. El gobernante insensato de Aristipo y su aparición en Ciropedia. Méthexis vol. 30, 1-24.

37. Jaeger, W. (2016 [1933]). Paideia, the Ideals of Greek Culture. Volume II: In Search of the Divine Center. Oxford: Oxford University Press.

38. Kant, I. (2007 [1785]). La metafísica de las costumbres. Trad. M García Morente. San Juan, Puerto Rico: Pedro M. Rosario Barbosa.

39. Kirk, G. S. (1969). Los Filósofos Presocráticos: Historia Crítica Conselección de Textos. Madrid: Gredos. 
40. Larmour D. H. J., Allen Miller, P. (eds.) (1998). Rethinking Sexuality: Foucault and Classical Antiquity. Princeton: Princeton University Press.

41. Liddell-Scott-Jones, A. (1940). Greek-English Lexicon. Oxford: Oxford University Press.

42. Lloyd-Jones, H. (1971). The Justice of Zeus. Berkeley: University of California Press.

43. Lozano Nembrot, M. (2017). La erótica griega y el problema de la enkrateia. En Actas del III Simposio Nacional de Filosofía Antigua (pp. 191-201). Mar del Plata: AAFA.

44. Lozano Nembrot, M. (2018). Lo erotikoì lógoi de Lisias y la moral griega. Symploké vol. 8, 51-67.

45. Marchant, E. C. (1900). Xenophontis opera omnia: Historia graeca (Vol. 1). E typographeo Clarendoniano.

46. Mársico, C. (2013). Filósofos socráticos, Testimonios y fragmentos I: Megáricos y Cirenáicos. Buenos Aires: Losada.

47. Mársico, C. (2013b). Filósofos socráticos, Testimonios y fragmentos II: Antístenes, Fedón, Esquines y Simón. Buenos Aires: Losada.

48. Mársico, C. T. (2011). "Ejes para pensar lo griego", en Mársico, C. T (ed.), Polythrýleta. Sistemas explicativos y mutación conceptual en el pensamiento griego. Buenos Aires: Rhesis.

49. Mondolfo, R. (1964). El humanismo de Marx. México-Buenos Aires: Fondo de Cultura Económica.

50. Mondolfo, R. (1997 [1962]). La conciencia moral de Homero a Demócrito y Epicuro. Buenos Aires: Eudeba.

51. Nietzsche (2012 [1872]). El Nacimiento de la Tragedia. Trad. A. Sánchez Pascual. Madrid: Alianza.

52. Nussbaum, M (1986). La fragilidad del bien: fortuna y ética en la tragedia y la filosofía. Madrid: Antonio Machado Libros.

53. Nussbaum, M. (1976). Consequences and character in Sophocles' Philoctetes. Philosophy and Literature, 1(1), 25-53. 
54. Onians, R. B. (1951) The Origins of European Thought about the Body, the Mind, the Soul, the World, Time and Fate. Cambridge: Cambridge University Press.

55. Oviedo, G. (2006). Rodolfo Mondolfo, Humanista de izquierda. Cuyo. Anuario de Filosofía Argentina y Americana, no 23, año 2006, 155-192.

56. Rademaker (2005). Sōphrosynē and the Rherotic of Self-Restraint: Polysemy and Persuasive Use of an Ancient Greek Value Term. Leiden: Brill.

57. Rohde, E. (2006 [1894]). Psique, La idea del alma y la inmortalidad entre los griegos, trad. W. Roces. México-Buenos Aires: Fondo de Cultura Económica

58. Rossetti, L. (2008). "Socrate enkrates". Zbornik Matice srpske za klasicne studije, No 10, 65-79.

59. Snell, B. (1953 [1946]). The Discovery of the Mind:The Greek Origins of European Thought, tr. TG Rosenmeyer. Cambridge: Harvard University Press.

60. Soares, L. (2000). Apuntes sobre la actualidad de la filosofía antigua. Espacios de crítica y producción № 26, 114-117.

61. Valenzuela, C. (2017). Escritos que quedan para semilla: el aula platónica como terreno de fecunda filosofía, Fierro, M.A. \& Valenzuela Issac, C. (eds.), “Retoños de Eros. Grafías y cinematografías platónicas", Aesthethika Revista internacional de estudio e investigación interdisciplinaria sobre subjetividad, política y arte, vol. 13., 5-9

62. Veggetti (2005 [1989]). La ética de los antiguos, trad. M. J. Rico Martínez. Madrid: Síntesis.

63. Voigt, C. (1972). Überlegung und Entscheidung. Meicheim: A. Hain.

64. Wald, B. (2003). Participación y personalidad. Anuario Filosófico XXXVI/1, 247269.

65. Williams, B. (1993). Shame and necessity. Berkeley: University of California Press. 